\title{
Study of Macrozoobenthic Diversity in the New River Flow of Pinang City, Labuhan Batu Selatan
}

\author{
Leli Febriani' ${ }^{1}$, Arman Harahap ${ }^{2}$ \\ ${ }^{1,2}$ Faculty of Teacher Training and Education, Universitas Labuhanbatu, Indonesia \\ armanhrp82@yahoo.co.id
}

\begin{abstract}
Benthos is an organism that lives on the bottom of the waters, both in the form of animals and plants, living on the surface and on the bottom of the waters. This study aims to determine the diversity of macrozoobenthic species in the Barumun River, Pinang City. The research starts from December 2020 to February 2021. Macrozoobenthic sampling using Surber net and Ekman Grab based on substrate differences in the riverbed. Macrozoobenthos found in the Barumun River in Pinang City consists of two phyla, namely Arthropoda and Molluscs. The phylum Arthropods found are from the class of insects belonging to the genera Hydropsyche, Polycentropus, psephenus, Dryops, Anthopotamu, Acroneuria and Triops. The phylum Molluscs found were from the Bilvavia class which belonged to the Corbicula genus and from the Gastropod class of the Genera Melanoides and Melanatria. The highest macrozoobenthic abudance at each station was Polycentropus (65,67 ind L) and Potadoma (265,67 ind L). The highest macrozoobenthic abudance found was Melanatria at (633,67 ind $L)$ based on the vulnerability index value $(H)(2,087-1,003)$ dominance index $(C)(0133-0,389)$ and evenness index $(E)(0,365-$ 0,603) Barumun River Kota Pinang is included in the good condition category with high species diversity. The physical and chemical factors of the waters are able to support macrozoobenthic life.
\end{abstract}

Keywords

diversity, macrozoobenthos, arthropods, mollusks, barumun river, Pinang city

\section{Introduction}

A river is a network of channels on the earth's surface that is scientifically formed, ranging from small in the upstream to large downstream (Lobies et al, 1993). Furthermore, it is stated that the rainwater that falls on the surface of the earth on its way a small part evaporates and most of it absorbs into the ground and some also flows to lower places, then becomes a channel which is gradually gathering into one large or main channel called and continue to flow into the sea. Thus it can be said that the river functions to accommodate rainfall and drain it into the sea.

Rivers are part of the freshwater ecosystem characterized by flow caused by currents. Flow is the flow of water that occurs due to vertical changes per unit length (Asdak, 1995). Furthermore, it was explained that rivers are also characterized by the presence of tributaries that collect and store and drain rainwater into the sea through the main rivers.

The Barumun River flows along the panai hulu sub-district of Labuhan Batu district to the sub-district area of the city of Pinang Labuhan Batu Selatan. The Barumun River is a large sunagi with a width of between $750-1050 \mathrm{~m}$, with a small river as a tributary/ branch. The estuary of the Barumun river is the Malacca Strait. 
Along the Barumun River, Kota Pinang District, Labuhan Batu Selatan Regency, there are various kinds of human activities, such as residential areas, agriculture, truck traffic, and industrial activities. The existence of these various activities can have a negative impact on water quality, including changes in the physical and chemical factors of the waters, so that it will have a negative impact on the life of aquatic organisms including macrozoobenthos.

Macrozoobenthic animals have an important role as a key in the food web that functions as predators, suspension feeders, detritivores and parasites (Jati, 2003). Macrozoobenthos are also used as bioindicators in the waters, because they are very sensitive to changes in the aquatic environment they occupy (Wilhm, 1975). The existence of macrozoobenthos can be seen from the substrate of the bottom waters which greatly determine the development of these organisms (Hynes, 1976). Rivers with fast flowing substrate in the form of rocks are more often found than Phylum Arthropoda and Mollusks. This substrate in the form of sand and mud is more often found from the Phylum Annelida and Molluscs.

Research related to the diversity of macrozoobenthic species conducted by Prima (2012) found 4 macrozoobenthic genera in the Barumun River, Pinang City, Teluk Batu Selatan. Yatini's research (2008) found 5 macrozobenthic genera in the waters of the Sail River Pekanbaru. The results of Erni's (2014) study found 8 macrozoobenthic genera in the yetai River, Deli Serdang Regency, North Sumatra Province. Until now, there is no data regarding the diversity of macrozoobenthos in the New Pinang River, considering the role and benefits of macrozoobenthos in the Rombok Banangar River.

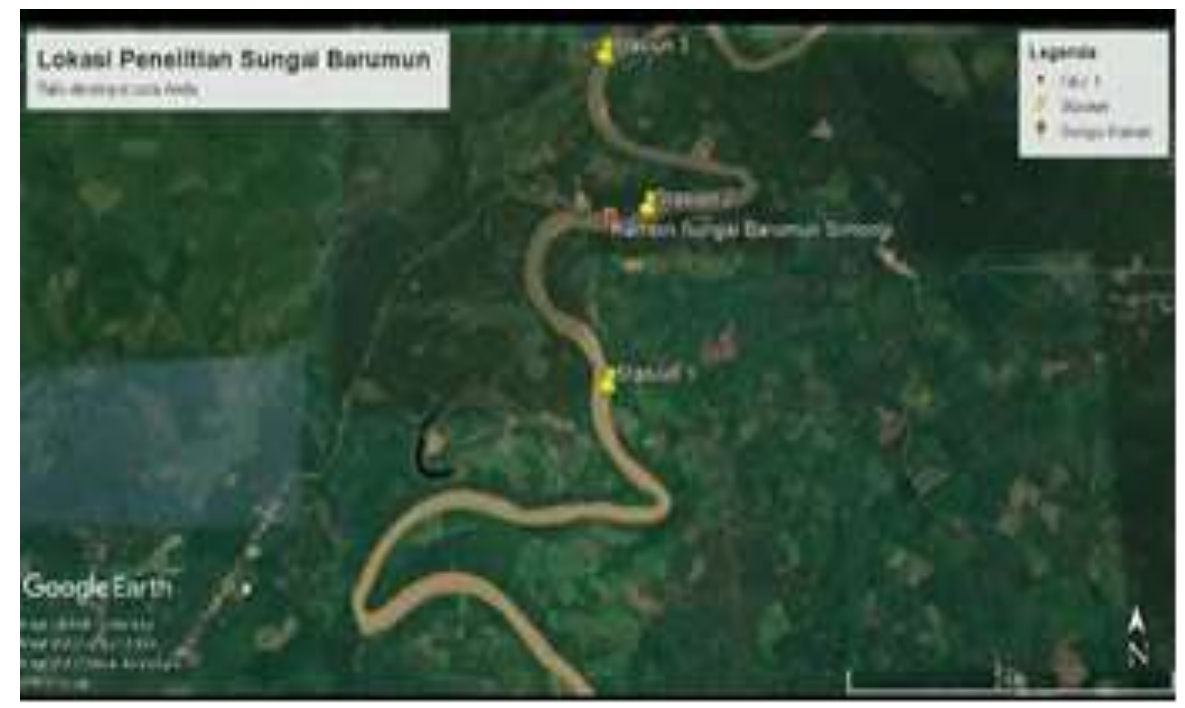

Figure 1. Map of the Research Location

\section{Research Methods}

\subsection{Time and Place of Research}

This research is a research with a qualitative descriptive approach that describes the diversity of Macrozoobenthos in the Barumun River, Kota Pinang District, Labuhan Batu Selatan Regency. This research was carried out by direct observation in the Barumun River, Kota Pinang District, Labuhan Batu Selatan Regency which is planned to be carried out from December to February 2021. 


\subsection{Tools and Materials}

The tools used in this research can be seen in the following table:

Table 1. Tools Used in Research

\begin{tabular}{|c|c|c|c|c|}
\hline No. & Parameter & Unit & Tool & The place \\
\hline 1. & Water temperature & ${ }^{\circ} \mathrm{C}$ & Mercury Thermometer & In-situ \\
\hline 2. & Light penetration & $\mathrm{Cm}$ & Seechi chip & In-situ \\
\hline 3. & Light intensity & Candela & Lux Meter & In-situ \\
\hline 4. & Current speed & $\mathrm{m} / \mathrm{sec}$ & Stopwatch, cork and meter & In-situ \\
\hline 5. & water $\mathrm{pH}$ & - & water $\mathrm{pH}$ & In-situ \\
\hline 6. & Oxygen saturation & $\%$ & - & In-situ \\
\hline 7. & Organic content & $\%$ & Oven and Furnace & Laboratory \\
\hline 8. & Sieve & - & Filter & In-situ \\
\hline 9. & Label & - & Sample identity & In-situ \\
\hline 10. & Camera & - & Documentation & In-situ \\
\hline 11. & Pen & - & Writing Sample Identity & In-situ \\
\hline
\end{tabular}

The materials used in the study were $4 \%$ formalin, $70 \%$ alcohol, MnSO4, KOH-KL, concentrated $\mathrm{H} 2 \mathrm{SO} 4$ solution, starch, $0,025 \mathrm{~N}$ sodium thiousulfate solution, $\mathrm{Na} 2 \mathrm{CO} 3$ solution and $0,5 \%$ phenolpthaelin indicator.

\subsection{General Description of the Research Location}

Barumun River is located in Kota Pinang District, Labuhan Batu Selatan Regency. The Barumun River flows along the panai hulu sub-district of Labuhan Batu district to the sub-district area of the city of Pinang Labuhan Batu Selatan. The Barumun River is a large sunagi with a width of between $750-1050 \mathrm{~m}$, with a small river as a tributary / branch. The estuary of the Barumun river is the Malacca Strait. Station I is located upstream with coordinate point GL: 10 50'6.17 "U GB: 1000 4'26.62" T Close to the city. At Station II GL: 10 50'37.36 "U GB: 1000 4'15.43" T. And at station III downstream GL: 10 50'4.34 "U GB: 1000 4'24.58" T

\subsection{Macrozoobenthic Sampling}

Macrozoobenthic sampling was carried out based on differences in environmental baseline on the substrate at each station, using the Cluster Random Sampling method which was divided into 3 stations. Sampling used Ekman Grab and Jala Surber. Sampling using Ekman Grab was carried out on a sandy and muddy substrate, with the open state of Ekman Grab being immersed in the bottom of the pendulum water being dropped so that the bottom part of the tool was tightly closed. The tool is pulled up and the sample is put into a plastic container labeled and given $4 \%$ alcohol. 


\section{Results and Discussion}

\subsection{Results}

Macrozoobenthos found in the three research stations in the new river flow in Kota Pinang District originated from Phylum Arthropoda and Molluscs. The phylum Arthropoda found came from the Insect Class. The phylum Molluscs found belong to the Gastropod and Bilvavian classes. Macrozoobenthos which are mostly found from Phylum Arthropoda are from the Order of Trichoptera with as many as 2 genera, while for Molluscs from the Order of Sorbeoconcha there are 3 genera (Table 2).

Based on the research results found at the three stations, the highest abundance of the genus macrozoobenthos at station I was Polycentropus at 65.67 ind / $\mathrm{m} 2$, at station II the Genus Melanantria had the highest abundance value of 633.67 ind / m2, while at Station III there were two genera which had the highest abundance value were Corbicula and Potadoma with an abundance value of 265.67 ind / $\mathrm{m} 2$ (Table 3).

Environmental parameters measured include temperature, $\mathrm{pH}$ and current velocity. The characteristic data of macroozoobenthic habitat at three stations of Sungai Barumun, Pinang City, Teluk Batu Selatan, shows that the water temperature ranges from $28-29 \mathrm{oC}$ with a current speed of 0.7-0.18m / s and a pH ranging from 7-8 (Table 4).

Macrozoobenthic communities in the Barumun River in Pinang City have varying levels of diversity based on differences in the riverbed substrate. The diversity of macrozoobenthos with rocky bottom substrate at station I was the highest with a value of 2.087 and the lowest was at station III (1.003) with a muddy bottom substrate (Table 4).

Table 2. Macrozoobenthos Found in the Barumun River in Pinang City

\begin{tabular}{|c|c|c|c|c|}
\hline Phylum & Class & Order & Family & Genera \\
\hline Athropod & Insects & $\begin{array}{l}\text { Trichoptera } \\
\text { Hydropsyche } \\
\text { Coleoptera } \\
\text { Odonata } \\
\text { Ephemeroptera } \\
\text { Plecoptera } \\
\text { Notoscrata }\end{array}$ & $\begin{array}{l}\text { Hydropsychidae } \\
\text { Polycentropodidae } \\
\text { Psephenidae } \\
\text { Driopidae } \\
\text { Potamanthidae } \\
\text { Anthopotamus } \\
\text { Perlidae } \\
\text { Triopsidae }\end{array}$ & $\begin{array}{l}\text { Polycentropus } \\
\text { Psephenus } \\
\text { Dryopus } \\
\text { Acroneuria } \\
\text { Triops }\end{array}$ \\
\hline \multirow[t]{2}{*}{ Molluscs } & Gastropods & Sorbeochonca & Thiaridae & $\begin{array}{c}\text { Melanoides } \\
\text { Potado } \\
\text { Melanantria }\end{array}$ \\
\hline & Balvavia & Verenoida & Corbiculidae & Corbitula \\
\hline
\end{tabular}




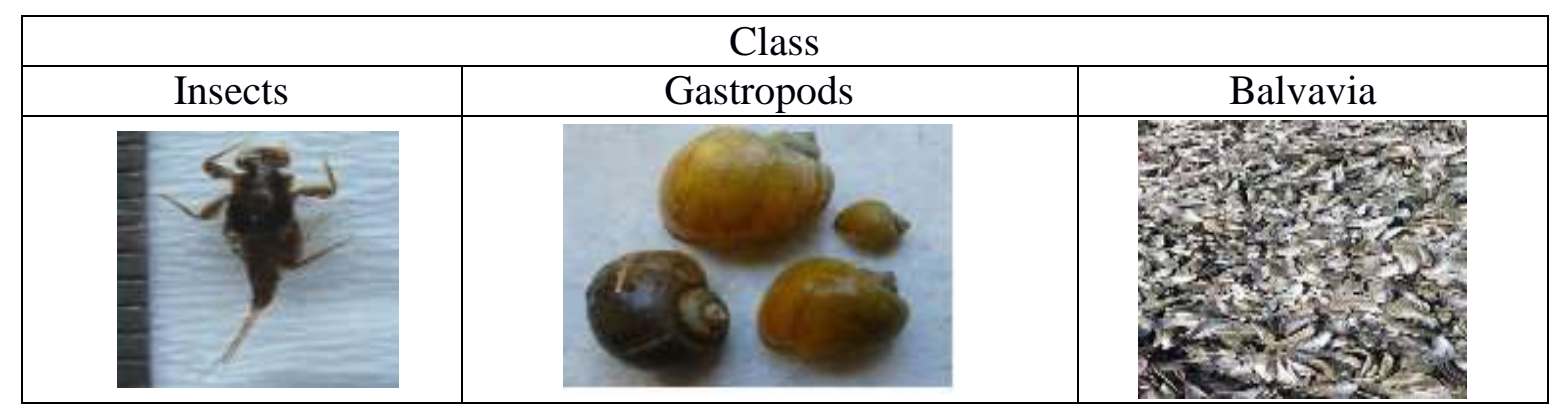

Table 3. Abundance (K) ind / $\mathrm{m} 2$, Relative Abundance (KR), and Relative Frequency (FR)\% at Each Macrozoobenthic Research Station in the New River Basin of Pinang City

\begin{tabular}{|c|c|c|c|c|c|c|c|c|c|}
\hline \multirow{2}{*}{ Genus } & \multicolumn{3}{|c|}{ Station I } & \multicolumn{3}{|c|}{ Station II } & \multicolumn{3}{|c|}{ Station III } \\
\hline & $\mathrm{K}$ & KR & FR & $\mathrm{K}$ & $\mathrm{KR}$ & FR & K & $\mathrm{KR}$ & FR \\
\hline Hydropsyche & 33,3 & 9,37 & 7,7 & - & - & - & - & - & - \\
\hline Polycentropus & $* * 65,67$ & 18,76 & 7,7 & - & - & - & - & - & - \\
\hline Psephenus & 22,2 & 6,24 & 7,7 & - & - & - & - & - & - \\
\hline Dryops & 22,2 & 6,24 & 7,7 & - & - & - & - & - & - \\
\hline Anthopotamus & 55,56 & 15,64 & 7,7 & - & - & - & - & - & - \\
\hline Acroneuria & 44,4 & 12,49 & 7,7 & - & - & - & - & - & - \\
\hline Triops & $* 12,1$ & 3,12 & 7,7 & - & - & - & - & - & - \\
\hline Melanoides & 55,56 & 15,64 & 23,1 & 266,67 & 20,69 & 33,3 & $* 88,89$ & 14,286 & 37,5 \\
\hline Melanantria & - & - & - & $* * 633,67$ & 48,27 & 11,1 & - & - & - \\
\hline Potadoma & 44,4 & 12,49 & 23,1 & 265,67 & 20,69 & 33,3 & $* * 265,67$ & $4,857$. & 37,5 \\
\hline Corbicula & - & - & - & $* 122,2$ & 10,345 & 22,2 & $* * 265,67$ & 42,857 & 25,0 \\
\hline
\end{tabular}

Note: (**) Highest Value and (*) Lowest Value

Table 4. Results of Measurement of Physical and Chemical Parameters for the Waters of the Barumun River in Pinang City at Each Penel Stationitian

\begin{tabular}{cccc} 
Index & \multicolumn{3}{c}{ Station } \\
\hline & I & II & III \\
\hline Shannon Winner Index $\left(\mathrm{H}^{\prime}\right)$ & 2,087 & 1,237 & 1,003 \\
Evenness Index $(\mathrm{E})$ & 0.603 & 0.365 & 0.380 \\
\hline Simpson Dominance Index (C) & 0.133 & 0.329 & 0.389 \\
\hline
\end{tabular}

\subsection{Discussions}

There are 11 genera of Macrozoobenthos found in the Barumun River, which are divided into two phyla, namely Arthropoda and Mollusks, and consist of Family Hydropsychidae, Polycentropodidae, Psephenidae, Driopidae, Potamanthidae, Perlidae and Triopsidae. The families included in the Phylum Molluscs are Thiaridae and Corbiculidae.

Phylum Arthropoda is a phylum that is mostly found in the new Sungai Pinang City. The phylum is mostly still in the larval stage. Many of these larvae were found because the Barumun River flow was very, very supportive for the growth of insect larvae. High levels of oxygen $(7-8 \mathrm{ppm})$ and the level of brightness in these waters $(8-58 \mathrm{~cm})$ are a supporting factor for the growth of insect larvae, with basic substrate conditions in the form of rocks and strong current velocities $(0.8 \mathrm{~m} / \mathrm{s})$. Cairns and Dickson (1981) explained that macrozoobenthos in the larval stage of insects are found in clear water with high enough oxygen levels. 
Polycentropus is a common genus of Phylum Arthropoda. This genus belongs to the order Trichoptera. Polycentropus has a morphology with one dorsal plate on the head, in each body segment it has a very soft texture and has a flat body shape (Pennak, 1978).

Station I is a station with a water base substrate in the form of rocks with a current velocity of $0.7 \mathrm{~m} / \mathrm{s}$ (Table 4), the highest abundance at station I is Polycentropus with an abundance value of 65.67 ind / $\mathrm{m} 2$ (Table 3). The high abundance of Polycentropus is because the substrate in the form of rocks is a good substrate for surviving heavy currents. Supporting body morphology with a pair of hook legs that function as a tool to attach oneself to the substrate (Pennak, 1978).

Another factor can be seen from the water $\mathrm{pH}$ level which reaches 7, which is a good $\mathrm{pH}$ value for Polycentropus life. According to Cairns and Dickson (1971), the types of may-flies (Ephemeroptera), stone-files (Plecoptera) and Caddies-files (Tricopthera) are found in clear water with $\mathrm{pH}$ values ranging from 6-8.

The lowest abundance at station I is Triops with an abundance value of 12.1 ind / $\mathrm{m} 2$ (Table 3). The low abundance of the Triops Genus is caused by water conditions at a rate of $(0.7 \mathrm{~m} / \mathrm{s})$ that are less supportive for Triops' life. The morphology of Triops is very small and soft, causing this genus to not be able to adapt well, making it easier to be carried away by currents. Triops are found in rivers that do not have fast current velocity and the abundance of this genus will appear high depending on several factors such as food quality (Cummins, 1975).

The sandy substrate is the flow of the Barumun River at station II with a current speed of $0.11 \mathrm{~m} / \mathrm{s}$ (Table 3). The highest abundance at station II was Genus Melanatria with an abundance value of 633.67 ind / $\mathrm{m} 2$ (Table 3). The high abundance of Melanantria is due to the sandy substrate which is suitable for the growth of the Genus Melanantria, supported by the large morphology of Melanantria among other Gastropods, making it easier for Melanantria to move to adapt. According to Suwignyo (1998), Melanantria is more commonly found in muddy and sandy waters because it is used as a place to get food and survive.

The lowest abundance at station II was Genus Corbicula with an abundance value of 122.2 ind / $\mathrm{m} 2$ (Table 3 ). The sandy substrate conditions are not very supportive for the growth of Corbicula, because Corbicula is a suspension-eating animal whose life is on the soft, non-sandy substrate. According to Nybaken (1992), bivalves are classified into groups of suspension, digging and deposit-eating animals, because of that their numbers tend to be abundant in muddy and soft sediments. Nontji (1987), also explained that Bilvavia is an animal that lives in the bottom of the waters by immersing itself in soft sediment.

Station III has a basic substrate in the form of mud. Macrozoobenthos were found in two genera which have the same high abundance value, with a value of 265.67 ind / $\mathrm{m} 2$ (Table 3), namely in the Genus Potadoma and Corbicula. The water condition at station III has a $\mathrm{pH}$ value of 7 with a current speed of $0.18 \mathrm{~m} / \mathrm{s}$ (Table 4).

The high abundance value in these two genera is supported by the substrate in the form of muddy sediments. The morphology of these two genera has a small shape compared to macrozoobenthos in the genus Melanantria. The smaller body shape causes Potadoma and Corbicula to be more active in order to survive. The $\mathrm{pH}$ value 6 is also one of the factors that support the growth of this genus. Hynes (1976), explains that gastropods are more commonly found in muddy waters to get food.

The lowest abundance at station III is in Genus Melanoides with an abundance of 88.89 ind $/ \mathrm{m} 2$. The low abundance of Melanoides is due to the unsupportive substrate, which is muddy. Melanoides are more commonly found in rocky substrate areas with high 
dissolved oxygen values. Erni (2014) explains that the Genus Melanoides lives in waters with high oxygen content and is able to survive in waters containing low organic matter.

The results showed that the Diversity Index value of the three research stations in the Barumun River, Pinang City ranged from 1.003 to 2.087 (Table 4). This value shows that the diversity at station I is still classified as good because the value $(\mathrm{H})$ is close to 3 , on the contrary, if the value of $\mathrm{H}$ 'is close to 0 , the diversity is low and the water conditions are not good (Odum, 1993). The high level of diversity at station I is due to good oxygen levels (6 ppm) (Table 3) and the condition of the existing water base substrate which is able to support the macrozoobenthic life.

The highest macrozoobenthic dominance index was 0.389 (Table 4), namely at station III with a muddy substrate. The dominant genera, namely Potadoma and Corbicula, have an abundance value that is very dominant among the existing genera.

The condition of environmental factors at the three water stations of the Barumun River in Pinang City still supports the macrozoobenthic life in these waters. The water temperature at the three stations ranges from $28-29 \mathrm{oC}$ (Table 4). In general, the temperature range is good enough for macrozoobenthic life. According to (Nybakken, 1992) the good temperature for macrozoobenthic life ranges from $26-30 \mathrm{oC}$.

The $\mathrm{pH}$ value at the three stations also affects the growth of macrozoobenthos in the waters, the results of $\mathrm{pH}$ measurements at each observation station range from 7-8 (Table 4). in the waters ranging from 6-8 (Soegianto, 2005).

Dissolved oxygen and $\mathrm{CO} 2$ in the waters is a very supportive factor for macrozoobenthic life. The results of the observations at the three stations that the dissolved oxygen values ranged from 6-7 ppm and the $\mathrm{CO} 2$ values at the three stations tended to be the same as $5 \mathrm{ppm}$ (Table 4). Oxygen in the waters is still very supportive for macrozoobenthic life because the minimum limit of dissolved $\mathrm{O} 2$ levels for aquatic organisms is 4 ppm (Suwondo, 2005).

\section{Conclusion}

Macrozoobenthos found in the Barumun River, Kota Pinang, Labuhan Batu Selatan. Generally, many people can be found from Insect, Gastropod and Balvavian classes and the Macrozoobenthic Diversity Index in the waters of the Barumun River, Pinang City is still very good.

\section{References}

Asdak, C. 1995. Hidrologi dan Pengelolaan Daerah Aliran Sungai. Cetakan ke 2. Yogyakarta: Universitas Gadjah Mada Press.

Cairns, JR \& KL, Dickson, 1971, Journal of the Water Control Federation, Vol.42.

Cairns, JR \& KI, Dickson, 1981, Biological Methods for Assesment of Water Quality, Merican Society Testing and Material (ASTM). America.

Cummins, KW, 1975, River Ecology, Editor Whitton, BA, Black Well Scients Publ. Oxford.

Efrizal, T, 2008, Struktur Komunitas Makrozoobentos Perairan Sungai Sail Kota Pekanbaru. Fakultas Perikanan dan Ilmu Kelautan, Universitas Riau Pekanbaru.

Erni, DF, 2014, Kondisi Perairan dan Struktur Komunitas Makrozoobentos di Sungai Belumai Kabupaten Deli Serdang Provinsi Sumatra Utara. Fakultas Perikanan dan Ilmu Kelautan, Isntitut Pertanian Bogor. Bogor 
Hynes, HBN. 1976. The Ekologi With Of Running Water. Liverpool University Press. England.

Jati, WN, 2011. Struktur Komparasi Keanekaragaman Bentos di Waduk Sempor, Waduk Kedungombo dan Waduk Gajah Mungkur Jawa Tengah, Fakultas Biologi Universitas Atmajaya, Yogyakarta.

Lind, OT, 1979, Hand Book of Common Methods in Limnology, Sec Ed, Mosby Company, St. Louis, Toronto, London.

Michael, P., 1984. Metode EkologiUntukPenyelidikanLadang dan Laboratorium, UIPress, Jakarta.Nybakken, JW, 1992, Biologi Laut, SuatuPendekatan

Ekologis, Gramedia, Jakarta.

Nontji, N, 1987, Laut Nusantara, Djamban, Jakarta.Blog <http://www.Academia.Edu/>.

Odum, EP, 1994. Dasar-Dasar Ekologi. Edisi ketiga. Universitas Gajah Mada Press. Yogyakarta.

Prima, SY, 2012, Kualitas Perairan Sungai Tebas Kecil di Tinjau Dari Struktur Komunitas Makrozoobentos, Fakultas Matematika dan Ilmu Pengetahuan Alam Universitas Tanjung Pura, Pontianak, Skripsi.

Pennak, RW, 1978, Freshwater Invertebrates of the United States, 2rd, ed. A, Willey Interscience Publ, Jhon Willey, NewYork.

Soegianto, A, 2005. Ilmu Lingkungan. Cetakan Pertama, Surabaya, Penerbit Universitas Airlangga.

Suwignyo, S, 1998, Avertebrata Air, Jilid I, Penerbit Penebar Swadaya.

Suwondo, EF, 2005, Struktur Komunitas Gastropoda pada Hutan Mangrove di Pulau Sipora Kepulauan Mentawai Sumatra Barat, Universitas Riau, Pekanbaru.

Wilhm, JF, 1975. Biological Indicators of Pollution, Dalam Whitton, BA, River Ecology, Blackwell Scient Publ, Oxford. 